\title{
Effect of Fertility Levels on Quality, Nutrient Content and Uptake of Single Cut Fodder Sorghum Genotypes
}

\author{
B.S. Meena*, V. Nepalia, Pragya Gautam and Kaushal Kishor
}

Department of Agronomy, Rajasthan College of Agriculture, Maharana Pratap University of Agriculture \& Technology, Udaipur-313001 (Rajasthan), India

*Corresponding author

\begin{tabular}{l} 
K e y w o r d s \\
$\begin{array}{l}\text { Single cut fodder } \\
\text { sorghum genotypes, } \\
\text { Fertility levels, HCN } \\
\text { content, Fodder quality, } \\
\text { Nutrient content and } \\
\text { uptake }\end{array}$ \\
\hline Article Info \\
$\begin{array}{l}\text { Accepted: } \\
\text { 24 February } 2018 \\
\text { Available Online: } \\
\text { 10 March } 2018\end{array}$ \\
\hline
\end{tabular}

\section{Introduction}

Sorghum is an important forage crop in India. As forage it is fast growing, palatable, nutritious and utilized as silage and hay besides fresh feeding. The yield potential of sorghum is much higher than other forage crops but the production is low (Singh et al., 2016). The economics of milk production is heavily dependent on the quantity of nutritious
A field experiment was conducted during kharif season of 2016 at Udaipur, Rajasthan on clay loam soil to assess the effect of fertility levels $\left(60 \mathrm{~N}+30 \mathrm{P}_{2} \mathrm{O}_{5}+30 \mathrm{~K}_{2} \mathrm{O} \mathrm{kg} \mathrm{ha}{ }^{-1}, 80 \mathrm{~N}\right.$ $+40 \mathrm{P}_{2} \mathrm{O}_{5}+40 \mathrm{~K}_{2} \mathrm{O} \mathrm{kg} \mathrm{ha}{ }^{-1}$ and $\left.100 \mathrm{~N}+50 \mathrm{P}_{2} \mathrm{O}_{5}+50 \mathrm{~K}_{2} \mathrm{O} \mathrm{kg} \mathrm{ha}{ }^{-1}\right)$ on single cut genotypes (SPH 1725, SPH 1794, SPH 1797, SPV 2317, CSH 13 and CSV 21F) of fodder sorghum. The SPH 1752 synthesized significantly higher chlorophyll content in leaves as compared to rest of genotypes. The lower HCN content in green forage was recorded in the genotype SPH 1797 as compared to other genotypes under test. The highest TSS was recorded in the genotype CSH 13. The genotype SPH 1752 exhibited maximum crude protein and crude fibre. The genotype SPV 2317 recorded maximum ether extract, nitrogen free extract and total digestible nutrient. While highest concentration of mineral ash was recorded in the genotype CSH 13. The maximum N, P and K content and uptake were recorded in the genotype SPH 1752 as compared to other genotypes. The crop fertilized with $100 \mathrm{~N}+50 \mathrm{P}_{2} \mathrm{O}_{5}+50 \mathrm{~K}_{2} \mathrm{O} \mathrm{kg} \mathrm{ha}{ }^{-1}$ recorded highest chlorophyll content and minimum $\mathrm{HCN}$ content in green fodder. This fertility level significantly increased content of crude protein, crude fibre, ether extract and mineral ash over lower fertility levels. Increasing fertility levels caused significant reduction in nitrogen free extract and total digestible nutrient content in dry fodder, which were highest with the application of $60 \mathrm{~N}+$ $30 \mathrm{P}_{2} \mathrm{O}_{5}+30 \mathrm{~K}_{2} \mathrm{O} \mathrm{kg} \mathrm{ha}{ }^{-1}$. The application of $100 \mathrm{~N}+50 \mathrm{P}_{2} \mathrm{O}_{5}+50 \mathrm{~K}_{2} \mathrm{O} \mathrm{kg} \mathrm{ha}{ }^{-1}$ recorded highest $\mathrm{N}, \mathrm{P}$ and $\mathrm{K}$ content and uptake over lower fertility levels. 
to play in determining the course and outcome of two major issues of interest in fertilizer management-namely, balanced fertilizer input and efficient fertilizer use. The $\mathrm{N}$ and $\mathrm{P}$ interaction can be termed the single most important nutrient interaction of practical significance. In addition to nitrogen, potassium is the major plant nutrient absorbed and removed by crops in the largest amounts among all essential nutrients.

The value of sorghum fodder has increased over the years compared to that of grain. But, one of the major factors limiting the utilization of sorghum fodder is the production of cyanogenic (HCN-producing) glycoside dhurin that lowers the nutritive value of fodder due to its toxic effects on the feeding livestock. Sorghum is considered to be a good feed in ordinary conditions but when it's normal growth is constrained by drought, or imbalanced soil nutrients, hydrocyanic acid (HCN) content may develop to such an extent that the toxic level may reach lethal level when fed to animals. Cyanide occurs in the leaves of sorghum as cyanogenic glucosidedhurin. Degradation of dhurin yields equimolar amount of hydrocyanic, glucose and P-hydroxybenzaldehyde (P-HB). During environmental stress and when leaf tissues are cracked large amount of dhurin may be produced rapidly. HCN production in forage is responsible for losses in livestock and hence, a great financial loss to poor rural livestock farmers of dry areas. The present work aimed to determine the relationship of sorghum $\mathrm{HCN}$ content with soil nitrogen and phosphorus, plant age at harvest, varieties of sorghum and find out determinants of reducing $\mathrm{HCN}$ content in Sorghum.

Identification of good quality sorghum genotypes and development of location specific production technology offer an excellent opportunity to provide fodder for better nutrition to bovine population of amongst growth factors, adequate inorganic fertilizers are considered to be of prime importance. Balanced and adequate use fertilizer has played a key role in the modernization of Indian agriculture and in making the country sufficient in fodder production for animals. Therefore, newly evolved single cut forage sorghum genotypes were grown to get information on their nutritive value under different fertility levels.

\section{Materials and Methods}

A field experiment was conducted during kharif season of 2016 at Instructional Farm, Rajasthan College of Agriculture, Udaipur (Rajasthan) situated at $24^{\circ} 35^{\prime} \mathrm{N}$ latitude, $74^{\circ} 42^{\prime} \mathrm{E}$ longitude and altitude of $579.5 \mathrm{~m}$ above mean sea level. The soil of the experimental field was clay loam in texture, slightly alkaline in reaction ( $\mathrm{pH} 8.20)$, low in available nitrogen $\left(248.1 \mathrm{~kg} \mathrm{ha}^{-1}\right)$ medium in organic carbon $(0.61 \%)$ and phosphorus $\left(20.60 \mathrm{~kg} \mathrm{ha} \mathrm{ha}^{-1}\right)$ and high in available potassium $\left(355.9 \mathrm{~kg} \mathrm{ha}^{-1}\right)$. The experiment consisted of 18 treatment combinations comprising six single cut fodder sorghum genotypes (SPH 1752, SPH 1794, SPH 1797, SPV 2317, CSH 13 and CSV 21F) and three fertility levels $\left(60 \mathrm{~N}+30 \mathrm{P}_{2} \mathrm{O}_{5}+30 \mathrm{~K}_{2} \mathrm{O} \mathrm{kg}\right.$ $\mathrm{ha}^{-1}, 80 \mathrm{~N}+40 \mathrm{P}_{2} \mathrm{O}_{5}+40 \mathrm{~K}_{2} \mathrm{O} \mathrm{kg} \mathrm{ha}{ }^{-1}$ and 100 $\mathrm{N}+50 \mathrm{P}_{2} \mathrm{O}_{5}+50 \mathrm{~K}_{2} \mathrm{O} \mathrm{kg} \mathrm{ha}{ }^{-1}$ ) laid out in Factorial Randomized Block Design and replicated thrice. As per treatment, full dose of phosphorus and potassium and half dose of nitrogen were applied at the time of sowing. Remaining half dose of nitrogen was top dressed at crop knee high stage. The sorghum genotypes as per treatment were sown on 09 July, 2016 in opened furrows at $30 \mathrm{~cm}$ apart using seed rate of $30 \mathrm{~kg} / \mathrm{ha}$. A plant to plant distance of $10 \mathrm{~cm}$ was maintained by thinning and gap filling operation at 15 DAS. Other agronomic and plant protection measures were adopted as and when crop needed. The crop was harvested at 50 per cent flowering stage. 


\section{Results and Discussion}

\section{Effect of genotypes}

The data (Table 1) reveal that in the genotype SPH 1752 recorded significantly higher chlorophyll content in leaves $\left(1.860 \mathrm{mg} \mathrm{g}^{-1}\right)$ over genotypes SPH 1797, CSV 21F and SPV 2317 by $4.49,7.51$ and 7.95 per cent, respectively. But it was found at par with the SPH 1794 and CSH 13. Whereas, the minimum HCN content $\left(0.140 \mathrm{mg} \mathrm{g}^{-1}\right)$ in green fodder at harvest was observed with the genotype SPH 1797, which was significantly lower than all other genotypes. The differences in HCN content in sorghum genotypes due to genetic makeup of different sorghum cultivars, climatic condition during the crop growth period and also affected by the enzymatic activity. Initial stage of crop has maximum HCN content, but it reduced significantly with increase in days after sowing up to harvest. The results are in agreement with findings of Kumar and Chaplot, 2015a. The highest TSS was recorded with CSH 13 (9.51\%), which was significantly superior over the rest of genotypes. Further the data explicit that the genotype SPH 1752 statistically at par with SPH 1794 and SPV 2317, but significantly higher over CSV 21F.

Single cut fodder sorghum genotype SPH 1752 registered maximum crude protein $(6.65 \%)$ and crude fibre $(30.28 \%)$ and genotype SPV 2317 recorded highest ether extract $(1.713 \%)$, nitrogen free extract $(58.35 \%)$ and total digestible nutrient (55.19\%), while genotype CSH 13 recorded highest mineral ash $(7.356 \%)$ in the dry fodder of the crop as compared to other genotypes. It was assumed that the nutritional values of the fodder crop also influenced with the genotypes. These results are in close agreement with the finding of Singh et al., 2014.
The data (Table 2) show that the maximum $\mathrm{N}$ content $(1.063 \%)$ was observed in the genotype SPH 1752, which was significantly higher over SPH 1797, CSV 21F, CSH 13 and SPV 2317 by 3.20, 7.37, 7.70 and 11.19 per cent, respectively, but at par with SPH 1794.

Likewise, the genotype SPH 1752 also registered highest $\mathrm{P}$ content $(0.243 \%)$, which was significantly superior over SPH 1794, CSH 13, CSV 21F and SPV 2317 by 5.19, $13.02,16.83$ and 22.73 per cent, respectively, but it, was at par with SPH 1797. Similarly, the genotype SPH 1752 contained maximum $\mathrm{K}(1.247 \%)$ which was significantly higher over the rest of genotypes except CSV 21F.

The data indicate that the highest $\mathrm{N}$ uptake $\left(151.58 \mathrm{~kg} \mathrm{ha}^{-1}\right), \mathrm{P}$ uptake $\left(34.71 \mathrm{~kg} \mathrm{ha}^{-1}\right)$ and $\mathrm{K}$ uptake $\left(177.74 \mathrm{~kg} \mathrm{ha}^{-1}\right)$ were recorded in the genotype SPH 1752, which was significantly superior over the genotypes CSH 13, CSV 21F, SPH 1794, SPH 1797 and SPV 3217. The significant increase in $\mathrm{N}, \mathrm{P}$ and $\mathrm{K}$ of fodder seems to be on account of capabilities of genotypes for efficient absorption, translocation and utilization of mineral nutrients. The results are in accordance with the finding of Duhan (2013).

\section{Effect of fertility levels}

The data (Table 1) show that maximum chlorophyll content in leaves $\left(1.810 \mathrm{mg} \mathrm{g}^{-1}\right)$ was observed with the application of $100+50+50 \mathrm{~kg} \mathrm{ha}^{-1}$ of $\mathrm{N}+\mathrm{P}_{2} \mathrm{O}_{5}+\mathrm{K}_{2} \mathrm{O}$, which was significantly higher over $60+30+30 \mathrm{~kg} \mathrm{ha}^{-}$ ${ }_{1}^{1}$ of $\mathrm{N}+\mathrm{P}_{2} \mathrm{O}_{5}+\mathrm{K}_{2} \mathrm{O}$ by 2.11 per cent, but at par with the application of $80+40+40 \mathrm{~kg} \mathrm{ha}^{-1}$ of $\mathrm{N}+\mathrm{P}_{2} \mathrm{O}_{5}+\mathrm{K}_{2} \mathrm{O}$. The fertility levels had significant effect on $\mathrm{HCN}$ content. The maximum $\mathrm{HCN}$ content $\left(0.185 \mathrm{mg} \mathrm{g}^{-1}\right)$ was observed with application of $60+30+30 \mathrm{~kg} \mathrm{ha}^{-1}$ of $\mathrm{N}+\mathrm{P}_{2} \mathrm{O}_{5}+\mathrm{K}_{2} \mathrm{O}$, which was significantly higher by 16.35 per cent over $80+40+40 \mathrm{~kg}$ ha $^{-1}$ of $\mathrm{N}+\mathrm{P}_{2} \mathrm{O}_{5}+\mathrm{K}_{2} \mathrm{O}$. 
Table.1 Effect of single cut fodder sorghum genotypes and fertility levels on fodder quality at harvest

\begin{tabular}{|c|c|c|c|c|c|c|c|c|c|}
\hline \multirow[t]{2}{*}{ Treatments } & \multicolumn{9}{|c|}{ Fodder quality traits (\%) } \\
\hline & $\begin{array}{c}\text { Chlorophyll } \\
\text { content } \\
\left(\mathrm{mg} \mathrm{g}^{-1}\right)\end{array}$ & $\begin{array}{c}\mathrm{HCN} \\
\text { content } \\
\left(\mathrm{mg} \mathrm{g}^{-1}\right)\end{array}$ & $\begin{array}{l}\text { TSS } \\
(\%)\end{array}$ & $\begin{array}{l}\text { Crude } \\
\text { protein }\end{array}$ & $\begin{array}{c}\text { Crude } \\
\text { fibre }\end{array}$ & $\begin{array}{c}\text { Ether } \\
\text { extract }\end{array}$ & $\begin{array}{c}\text { Mineral } \\
\text { ash }\end{array}$ & $\begin{array}{c}\text { Nitrogen } \\
\text { free } \\
\text { extract }\end{array}$ & $\begin{array}{c}\text { Total } \\
\text { digestible } \\
\text { nutrient }\end{array}$ \\
\hline \multicolumn{10}{|l|}{ Genotypes } \\
\hline SPH 1752 & 1.860 & 0.162 & 7.66 & 6.65 & 30.28 & 1.673 & 7.209 & 54.19 & 54.96 \\
\hline SPH 1794 & 1.811 & 0.198 & 7.53 & 6.46 & 28.97 & 1.673 & 7.099 & 55.80 & 55.07 \\
\hline SPH 1797 & 1.780 & 0.140 & 7.99 & 6.44 & 29.07 & 1.653 & 7.156 & 55.69 & 55.03 \\
\hline SPV 2317 & 1.723 & 0.172 & 7.44 & 5.97 & 26.88 & 1.713 & 7.083 & 58.35 & 55.19 \\
\hline CSH 13 & 1.803 & 0.164 & 9.51 & 6.17 & 28.46 & 1.683 & 7.356 & 56.33 & 54.97 \\
\hline CSV 21F & 1.730 & 0.163 & 7.04 & 6.19 & 28.19 & 1.661 & 7.311 & 56.65 & 54.99 \\
\hline SEm \pm & 0.021 & 0.004 & 0.08 & 0.07 & 0.34 & 0.013 & 0.057 & 0.45 & 0.04 \\
\hline CD 5\% & 0.060 & 0.012 & 0.22 & 0.20 & 0.97 & 0.037 & 0.163 & 1.31 & 0.12 \\
\hline \multicolumn{10}{|c|}{$\begin{array}{l}\text { Fertility Levels } \\
\left(\mathrm{N}+\mathrm{P}_{2} \mathrm{O}_{5}+\mathrm{K}_{2} \mathrm{O} \mathrm{kg} \mathrm{ha}{ }^{-1}\right)\end{array}$} \\
\hline $60+30+30$ & 1.753 & 0.185 & 8.14 & 6.21 & 26.86 & 1.653 & 7.127 & 58.14 & 55.11 \\
\hline $80+40+40$ & 1.790 & 0.159 & 7.88 & 6.28 & 28.71 & 1.679 & 7.197 & 56.13 & 55.04 \\
\hline $100+50+50$ & 1.810 & 0.155 & 7.56 & 6.44 & 30.35 & 1.696 & 7.284 & 54.24 & 54.96 \\
\hline SEm \pm & 0.015 & 0.003 & 0.06 & 0.05 & 0.24 & 0.009 & 0.040 & 0.32 & 0.03 \\
\hline CD 5\% & 0.043 & 0.008 & 0.16 & 0.14 & 0.68 & 0.026 & 0.115 & 0.92 & 0.09 \\
\hline
\end{tabular}


Table.2 Effect of single cut fodder sorghum genotypes and fertility levels on nutrient content and uptake by fodder at harvest

\begin{tabular}{|c|c|c|c|c|c|c|}
\hline \multirow[t]{2}{*}{ Treatments } & \multicolumn{3}{|c|}{ Content (\%) } & \multicolumn{3}{|c|}{ Uptake (kg ha $\left.{ }^{-1}\right)$} \\
\hline & $\mathbf{N}$ & $\mathbf{P}$ & $\mathbf{K}$ & $\mathbf{N}$ & $\mathbf{P}$ & $\mathbf{K}$ \\
\hline \multicolumn{7}{|l|}{ Genotypes } \\
\hline SPH 1752 & 1.063 & 0.243 & 1.247 & 151.58 & 34.71 & 177.74 \\
\hline SPH 1794 & 1.033 & 0.231 & 1.214 & 106.98 & 23.92 & 125.74 \\
\hline SPH 1797 & 1.030 & 0.237 & 1.214 & 106.76 & 24.53 & 125.72 \\
\hline SPV 2317 & 0.956 & 0.198 & 1.128 & 93.10 & 19.32 & 109.87 \\
\hline CSH 13 & 0.987 & 0.215 & 1.202 & 125.33 & 27.32 & 152.76 \\
\hline CSV 21F & 0.990 & 0.208 & 1.228 & 107.28 & 22.57 & 132.97 \\
\hline SEm \pm & 0.011 & 0.003 & 0.011 & 4.47 & 1.01 & 5.30 \\
\hline CD 5\% & 0.031 & 0.007 & 0.031 & 12.85 & 2.90 & 15.22 \\
\hline \multicolumn{7}{|c|}{$\begin{array}{l}\text { Fertility Levels } \\
\left(\mathrm{N}+\mathrm{P}_{2} \mathrm{O}_{5}+\mathrm{K}_{2} \mathrm{O} \mathrm{kg} \mathrm{ha}\right. \\
\end{array}$} \\
\hline $60+30+30$ & 0.994 & 0.219 & 1.189 & 103.98 & 22.97 & 124.22 \\
\hline $80+40+40$ & 1.005 & 0.222 & 1.204 & 114.94 & 25.39 & 137.97 \\
\hline $100+50+50$ & 1.030 & 0.226 & 1.224 & 126.60 & 27.83 & 150.22 \\
\hline SEm \pm & 0.008 & 0.002 & 0.008 & 3.16 & 0.71 & 3.74 \\
\hline CD 5\% & 0.022 & 0.005 & 0.022 & 9.08 & 2.05 & 10.76 \\
\hline
\end{tabular}


Though, the minimum HCN content $(0.155 \mathrm{mg}$ $\left.\mathrm{g}^{-1}\right)$ was observed with application of $100+50+50 \mathrm{~kg} \mathrm{ha}^{-1}$ of $\mathrm{N}+\mathrm{P}_{2} \mathrm{O}_{5}+\mathrm{K}_{2} \mathrm{O}$. The $\mathrm{HCN}$ content was maximum at germination and then continuously decreased with age 30 DAS stage, the content of dhurin correlated with the activity of two biosynthetic enzymes, CYP 79 A1 and CYP 76 E1 and with protein and mRNA level for the two enzymes.

During dhurin development, the activity of CYP 79 A1 was lower than the activity of CYP 76 E1 suggesting that CYP 79 A1 catalyzes the rate limiting set up using etiolated seedling.

The site of dhurin synthesis shifts from leaves to stem during plant development. The application of $60 \mathrm{~kg} \mathrm{~N}+30 \mathrm{~kg} \mathrm{P}_{2} \mathrm{O}_{5}+30 \mathrm{~kg} \mathrm{~K} 2 \mathrm{O}$ $\mathrm{ha}^{-1}$ produced highest TSS $(8.14 \%)$, which was significantly higher over $80 \mathrm{~kg} \quad \mathrm{~N}+40 \mathrm{~kg}$ $\mathrm{P}_{2} \mathrm{O}_{5}+40 \mathrm{~kg} \mathrm{~K}_{2} \mathrm{O} \mathrm{ha}^{-1}$ and $100 \mathrm{~kg} \mathrm{~N}+50 \mathrm{~kg}$ $\mathrm{P}_{2} \mathrm{O}_{5}+50 \mathrm{~kg} \mathrm{~K}_{2} \mathrm{O}$ ha $^{-1}$ by 3.30 and 7.67 per cent, respectively.

The crop fertilized with $100+50+50 \mathrm{~kg} \mathrm{ha}^{-1}$ of $\mathrm{N}+\mathrm{P}_{2} \mathrm{O}_{5}+\mathrm{K}_{2} \mathrm{O}$ recorded highest crude protein content $(6.44 \%)$, which was significantly higher over $80+40+40 \mathrm{~kg} \mathrm{ha}^{-1}$ and $60+30+30 \mathrm{~kg}$ ha $^{-1}$ of $\mathrm{N}+\mathrm{P}_{2} \mathrm{O}_{5}+\mathrm{K}_{2} \mathrm{O}$. The corresponding increase in crude protein content with application of $100+50+50 \mathrm{~kg} \mathrm{ha}$ of $\mathrm{N}+\mathrm{P}_{2} \mathrm{O}_{5}+\mathrm{K}_{2} \mathrm{O}$ over $60+30+30 \mathrm{~kg} \mathrm{ha}^{-1}$ and $80+40+40 \mathrm{~kg} \mathrm{ha}^{-1}$ of $\mathrm{N}+\mathrm{P}_{2} \mathrm{O}_{5}+\mathrm{K}_{2} \mathrm{O}$ were of the order of 3.70 and 2.55 per cent, respectively.

The highest crude fibre $(30.35 \%)$ recorded with the application of $100+50+50 \mathrm{~kg} \mathrm{ha}^{-1}$ of $\mathrm{N}+\mathrm{P}_{2} \mathrm{O}_{5}+\mathrm{K}_{2} \mathrm{O}$. An application of $100+50+50 \mathrm{~kg}$ $\mathrm{ha}^{-1}$ of $\mathrm{N}+\mathrm{P}_{2} \mathrm{O}_{5}+\mathrm{K}_{2} \mathrm{O}$ significantly increase crude fibre content of fodder by 5.71 and 12.99 per cent over the application of $80+40+40 \mathrm{~kg}$ $\mathrm{ha}^{-1}$ and $60+30+30 \mathrm{~kg} \mathrm{ha}^{-1}$ of $\mathrm{N}+\mathrm{P}_{2} \mathrm{O}_{5}+\mathrm{K}_{2} \mathrm{O}$, respectively. The application of $80 \mathrm{~kg} \mathrm{~N}+40 \mathrm{~kg}$ $\mathrm{P}_{2} \mathrm{O}_{5}+40 \mathrm{~kg} \mathrm{~K} \mathrm{~K}_{2} \mathrm{O} \mathrm{ha}^{-1}$ significantly increase ether extract by 1.57 per cent over the application of $60 \mathrm{~kg} \mathrm{~N}+30 \mathrm{~kg} \mathrm{P}_{2} \mathrm{O}_{5}+30 \mathrm{~kg} \mathrm{~K}_{2} \mathrm{O}$ $\mathrm{ha}^{-1}$. Further increase in fertility level failed to exhibit significant result.
Though increasing rate of fertility level from 60 $\mathrm{kg} \mathrm{N}, 30 \mathrm{~kg} \mathrm{P}_{2} \mathrm{O}_{5}$ and $30 \mathrm{~kg} \mathrm{~K}_{2} \mathrm{O} \mathrm{ha}^{-1}$ did not affect the mineral ash content, but further increase of fertility level upto $100 \mathrm{~kg} \mathrm{~N}, 50 \mathrm{~kg}$ $\mathrm{P}_{2} \mathrm{O}_{5}$ and $50 \mathrm{~kg} \mathrm{~K}_{2} \mathrm{O}$ ha ${ }^{-1}$ gave significantly high mineral ash content over preceding level. The highest nitrogen free extract $(58.14 \%)$ was recorded with the conjoint application of $60 \mathrm{~kg}$ $\mathrm{N}, 30 \mathrm{~kg} \mathrm{P}_{2} \mathrm{O}_{5}$ and $30 \mathrm{~kg} \mathrm{~K}_{2} \mathrm{O}$ ha $^{-1}$. There was a significant drop down in nitrogen free extract by raising fertility level upto $100 \mathrm{~kg} \mathrm{~N}, 50 \mathrm{~kg}$ $\mathrm{P}_{2} \mathrm{O}_{5}$ and $50 \mathrm{~kg} \mathrm{~K}_{2} \mathrm{O}$ ha $^{-1}$.

The maximum total digestible nutrient content $(55.11 \%)$ was recorded with the application of $60+30+30 \mathrm{~kg} \mathrm{ha}^{-1}$ of $\mathrm{N}+\mathrm{P}_{2} \mathrm{O}_{5}+\mathrm{K}_{2} \mathrm{O}$, which was significantly higher over the $100+50+50 \mathrm{~kg} \mathrm{ha}^{-1}$ of $\mathrm{N}+\mathrm{P}_{2} \mathrm{O}_{5}+\mathrm{K}_{2} \mathrm{O}$, but it was statistically at par with $80+40+40 \mathrm{~kg} \mathrm{ha}^{-1}$ of $\mathrm{N}+\mathrm{P}_{2} \mathrm{O}_{5}+\mathrm{K}_{2} \mathrm{O}$.

It was made clear that the maximum concentration of crude protein, crude fibre, ether extract and mineral ash were observed with the application of $100 \mathrm{~kg} \mathrm{~N}, 50 \mathrm{~kg} \mathrm{P}_{2} \mathrm{O}_{5}$ and $50 \mathrm{~kg} \mathrm{~K}_{2} \mathrm{O} \mathrm{ha}{ }^{-1}$. While the concentration of nitrogen free extract and total digestible nutrient content decreased with increasing fertility level and highest content of nitrogen free extract and total digestible nutrient were recorded with the application of $60 \mathrm{~kg} \mathrm{~N}, 30 \mathrm{~kg} \mathrm{P}_{2} \mathrm{O}_{5}$ and $30 \mathrm{~kg}$ $\mathrm{K}_{2} \mathrm{O}$ ha $^{-1}$ (Rana et al., 2013 and Kumar and Chaplot, 2015b).

The data (Table 2) show that the maximum $\mathrm{N}$ content $(1.030 \%)$ was recorded with the application of $\mathrm{N}, \mathrm{P}_{2} \mathrm{O}_{5}$ and $\mathrm{K}_{2} \mathrm{O} @ 100,50$ and $50 \mathrm{~kg} \mathrm{ha}^{-1}$, which was significantly higher over $\mathrm{N}, \mathrm{P}_{2} \mathrm{O}_{5}$ and $\mathrm{K}_{2} \mathrm{O} @ 80,40$ and $40 \mathrm{~kg} \mathrm{ha}^{-1}$ and $\mathrm{N}, \mathrm{P}_{2} \mathrm{O}_{5}$ and $\mathrm{K}_{2} \mathrm{O} @ 60,30$ and $30 \mathrm{~kg} \mathrm{ha}^{-1}$ by 2.49 and 3.62 per cent, respectively. The maximum $\mathrm{P}$ content $(0.226 \%)$ was registered with the application of $100+50+50 \mathrm{~kg} \mathrm{ha}^{-1}$ of $\mathrm{N}+\mathrm{P}_{2} \mathrm{O}_{5}+\mathrm{K}_{2} \mathrm{O}$ over $60+30+30 \mathrm{~kg} \mathrm{ha}^{-1}$ of $\mathrm{N}+\mathrm{P}_{2} \mathrm{O}_{5}+\mathrm{K}_{2} \mathrm{O}$ by 3.19 per cent, but it was at par with the application of $80+40+40 \mathrm{~kg} \mathrm{ha}^{-1}$ of $\mathrm{N}+\mathrm{P}_{2} \mathrm{O}_{5}+\mathrm{K}_{2} \mathrm{O}$. The maximum $\mathrm{K}$ content $(1.224$ $\%)$ was observed with the application of $100+50+50 \mathrm{~kg} \mathrm{ha}^{-1}$ of $\mathrm{N}+\mathrm{P}_{2} \mathrm{O}_{5}+\mathrm{K}_{2} \mathrm{O}$, which was significantly higher over $60+30+30 \mathrm{~kg} \mathrm{ha}^{-1}$ of 
$\mathrm{N}+\mathrm{P}_{2} \mathrm{O}_{5}+\mathrm{K}_{2} \mathrm{O}$ by 2.94 per cent, but at par with the application of $80+40+40 \mathrm{~kg} \mathrm{ha}^{-1}$ of $\mathrm{N}+\mathrm{P}_{2} \mathrm{O}_{5}+\mathrm{K}_{2} \mathrm{O}$. The estimation of nutrient concentration revealed marked improvement in nitrogen, phosphorus and potassium status in fodder at harvest with application of nitrogen, phosphorus and potassium fertilizers. The marked improvement in nitrogen content of vegetative parts seems to be on account of its greater availability in soil environment and translocation in plant system. Further, it has been reported that shoot and root growth mutually inherent with each other.

The crop fertilized with $100 \mathrm{~kg} \mathrm{~N}+50 \mathrm{~kg}$ $\mathrm{P}_{2} \mathrm{O}_{5}+50 \mathrm{~kg} \mathrm{~K}_{2} \mathrm{O}$ ha $^{-1}$ recorded highest $\mathrm{N}$ uptake $\left(126.60 \mathrm{~kg} \mathrm{ha}^{-1}\right)$ and $\mathrm{P}$ uptake $\left(27.83 \mathrm{~kg} \mathrm{ha}^{-1}\right)$, which were significantly higher over the application of $80 \mathrm{~kg} \mathrm{~N}+40 \mathrm{~kg} \mathrm{P}_{2} \mathrm{O}_{5}+40 \mathrm{~kg} \mathrm{~K} 2 \mathrm{O}$ $\mathrm{ha}^{-1}$ and $60 \mathrm{~kg} \mathrm{~N}+30 \mathrm{~kg} \mathrm{P}_{2} \mathrm{O}_{5}+30 \mathrm{~kg} \mathrm{~K}_{2} \mathrm{O} \mathrm{ha}^{-1}$ by 10.14 and 21.75 per cent and 9.61 and 21.15 per cent, respectively. Increasing rate of nutrient application up $100 \mathrm{~kg} \mathrm{~N}+50 \mathrm{~kg} \mathrm{P}_{2} \mathrm{O}_{5}+50 \mathrm{~kg}$ $\mathrm{K}_{2} \mathrm{O}$ ha $^{-1}$ tended to result in significantly higher $\mathrm{K}$ uptake. It is an established fact that accumulation of nutrients is dependent on their concentration at cellular level and dry matter production. Thus, impact of nitrogen, phosphorus and potassium fertilizer on their ultimately led to higher accumulation of nutrients by plant parts along with total uptake by the crop. The results are in close agreement with the finding of several researchers (Rao et al., 2007 and Gupta et al., 2015).

\section{References}

Duhan, B., S. 2013. Effect of integrated nutrient management on yield and nutrient uptake by sorghum (Sorghum bicolor L.) genotypes. Forage Research 39(3): 156158.

Gupta, G., Dhaka, S.K. and Sumeriya, H.K. 2015. Effect of fertility levels on yield and nutritional status of sorghum [Sorghum bicolor (L.) Moench] genotypes. International Journal of Environmental Science 3(Special issue): 241-244.

Kumar, D. and Chaplot, P.C. 2015a. Effect of fertility levels on quality of multi cut forage sorghum genotypes. Forage Research 40(4): 251-253.

Kumar, D. and Chaplot, P.C. 2015b. Effect of multi cut forage sorghum genotypes and fertility levels on nutrient uptake and soil nutrient balance. Forage Research 41(1): 50-52.

Rana, D.S., Singh, B., Gupta, K. and Dhaka, A.K. 2013. Performance of single-cut forage sorghum genotypes to different fertility levels. Forage Research 39(2): 96-98.

Rao, S.S., Regar, P. L., Jagid, B. L. and Singh, Y. V. 2007. Effect of nutrient and weed management on forage sorghum [Sorghum bicolor (L.) Moench] under rainfed condition. Indian Journal of Agronomy 52(2): 139-142.

Singh, K.P., Chaplot, P.C., Sumeriya, H.K. and Choudhary, G.L. 2016. Performance of single cut forage sorghum genotypes to fertility levels. Forage Research, 42(2): 140-142.

Singh, P., Sumeriya, H.K. and Meena, A.K. 2014. Response of sorghum [Sorghum bicolor (L.) Moench] single cut forage genotypes to nitrogen levels. Annals of Agri-Bio Research 19(1): 55-60.

\section{How to cite this article:}

Meena, B.S., V. Nepalia, Pragya Gautam and Kaushal Kishor. 2018. Effect of Fertility Levels on Quality, Nutrient Content and Uptake of Single Cut Fodder Sorghum Genotypes. Int.J.Curr.Microbiol.App.Sci. 7(03): 2859-2865. doi: https://doi.org/10.20546/ijcmas.2018.703.329 